\title{
Clonal structure and high genetic diversity at peripheral populations of Sorbus torminalis (L.) Crantz.
}

\author{
Sandra Jankowska-Wroblewska, \\ Katarzyna Meyza, Ewa \\ Sztupecka, Lukasz Kubera, \\ Jaroslaw Burczyk
}

\begin{abstract}
Knowing the level of genetic diversity and structure in marginal plant populations is essential for managing their genetic resources. This is particularly important for rare scattered tree species, such as Sorbus torminalis (L.) Crantz. We investigated the genetic diversity and its spatial distribution in peripheral populations of $S$. torminalis. As the species is known to reproduce vegetatively, we also evaluated clonal structure within populations. Using 13 nuclear microsatellite loci designed in two multiplexes, we genotyped 172 individuals revealing the existence of 100 distinct genotypes. Number of ramets per genotype was variable across populations with an average of 1.72. Examples of somaclonal variation at particular loci were detected. Measures of genetic diversity of the total sample were relatively high (mean allelic richness $A R=10.293$; expected heterozygosity $H_{\mathrm{e}}=0.756$ ), as compared to other $S$. torminalis populations. We noticed a slightly negative inbreeding coefficient $\left(F_{\text {IS }}=-0.029\right)$ indicating a small excess of heterozygotes, which is typical for self-incompatible plants. Genetic differentiation among populations was low $\left(F_{\mathrm{ST}}=0.048\right)$, but Bayesian clustering methods revealed the existence of three distinct genetic clusters only in part related to population structure. Significant spatial genetic structure within populations was also detected $(S p=$ 0.0125 ) indicating fine-scale pattern of isolation by distance. Our study demonstrated that peripheral populations of $S$. torminalis may exhibit relatively high levels of genetic diversity despite the existence of vegetative propagation. Nevertheless, if the studied or similar populations are expected to be utilized as seed sources for ex-situ or in-situ conservation purposes, the existence of clonal structure and spatial genetic structure must be taken into account in order to avoid excessive sampling of the same or closely related genets.
\end{abstract}

Keywords: Sorbus torminalis, Clonality, Range Limits, Somatic Mutations, Microsatellites

tion (Eckert et al. 2008). This is mostly due to the increased fragmentation of populations towards range limits, coupled with restricted gene exchange among populations. Consequently, loss of genetic diversity is more likely in small isolated peripheral populations due to random genetic drift (Young et al. 1996). Therefore, peripheral populations may evolve separately from the core populations (García-Ramos \& Kirkpatrick 1997) and may possess unique genetic variation due to local adaptation to marginal habitats. Their genetic

$\square$ Institute of Experimental Biology, Department of Genetics, Kazimierz Wielki University of Bydgoszcz, Chodkiewicza 30, 85-064 Bydgoszcz (Poland)

@ Jaroslaw Burczyk (burczyk@ukw.edu.pl)

Received: Sep 27, 2015 - Accepted: Feb 02, 2016

Citation: Jankowska-Wroblewska S, Meyza K, Sztupecka E, Kubera L, Burczyk J (2016). Clonal structure and high genetic diversity at peripheral populations of Sorbus torminalis (L.) Crantz.. iForest 9: 892-900. - doi: 10.3832/ifor1885-009 [online 2016-05-29]

pool might be important for maintaining the overall species capacity to evolve and adapt to changing environmental conditions (Lesica \& Allendorf 1995).

Climate changes predicted in Europe are expected to affect a number of plant species, including forest trees (Koskela et al. 2007). Although changing climatic conditions may cause the loss of existing habitats, there may also be opportunities for some species to colonize new areas where climate conditions will become more favorable (Hedhly et al. 2009, Kramer \& Havens 2009). Thus, knowledge of genetic diversity in peripheral populations may be useful in designing conservation strategies for a species and assessing potential for its further spread.

Forest management practices in Central Europe favor dense, even aged forests with closed-canopies. This causes the loss of habitats for many other early successional tree species of lower economical importance. One such example is the wild service tree (Sorbus torminalis [L.] Crantz), a typical forest companion tree species. The species occurs in small, isolated groups or as scattered individual trees (Angelone 
Tab. 1 - Extent of clonality in populations of Sorbus torminalis in the Forest District Jamy, Poland. $(\mathrm{N})$ : Number of ramets (trees); $(\mathrm{G})$ : number of genets; $(\mathrm{N} / \mathrm{G})$ : mean number of ramets/genet; $\left(\mathrm{N}_{\mathrm{c}}\right)$ : number of clonal groups; $(\mathrm{R})$ : clonal richness $[=(\mathrm{G}-1)$ / $(\mathrm{N}-1)] ;(1-\mathrm{R})$ : extent of clonality.

\begin{tabular}{|c|c|c|c|c|c|c|}
\hline Population & N & G & N/G & $\begin{array}{c}\mathrm{N}_{\mathrm{c}} \\
\text { (no. ramets/group) }\end{array}$ & $\mathbf{R}$ & $(1-R)$ \\
\hline 1. Dusocin & 25 & 19 & 1.316 & $\begin{array}{c}4 \\
(2,2,3,3)\end{array}$ & 0.750 & 0.250 \\
\hline 2. Zarosle & 7 & 7 & 1.000 & 0 & 1.000 & 0.000 \\
\hline 3. Rogozno & 75 & 30 & 2.500 & $\begin{array}{c}12 \\
(2,2,2,2,2,3,3 \\
4,4,4,7,17)\end{array}$ & 0.392 & 0.608 \\
\hline 4. Lysakowo & 49 & 31 & 1.581 & $(2,2,2,3,3,4,5,5)$ & 0.625 & 0.377 \\
\hline 5. Osa Valley & 16 & 13 & 1.231 & $\begin{array}{c}1 \\
(4)\end{array}$ & 0.800 & 0.200 \\
\hline All & 172 & 100 & 1.720 & 25 & 0.579 & 0.421 \\
\hline
\end{tabular}

et al. 2007, Demesure-Musch \& Oddou-Muratorio 2004, Hoebee et al. 2006, Rasmussen \& Kollmann 2004). It is distributed across western, central and south-western parts of Europe, but occurs also in northern Africa and in south-western Asia (Demesure-Musch \& Oddou-Muratorio 2004). The species reaches its north-eastern range limit in Poland, where it grows in small scattered populations, mainly in the western part of the country (Bednorz 2004). In Poland the species is classified as endangered and protected by state law (Bednorz 2007).

Wild service tree is pollinated by insects (hymenopteran or dipteran) and is capable of long distance pollen dispersal (OddouMuratorio et al. 2003, 2004). The species is characterized by gametophytic self-incompatibility system (Ludwig et al. 2013) suggesting a predominantly outcrossing mating system (but see Hoebee et al. 2007).

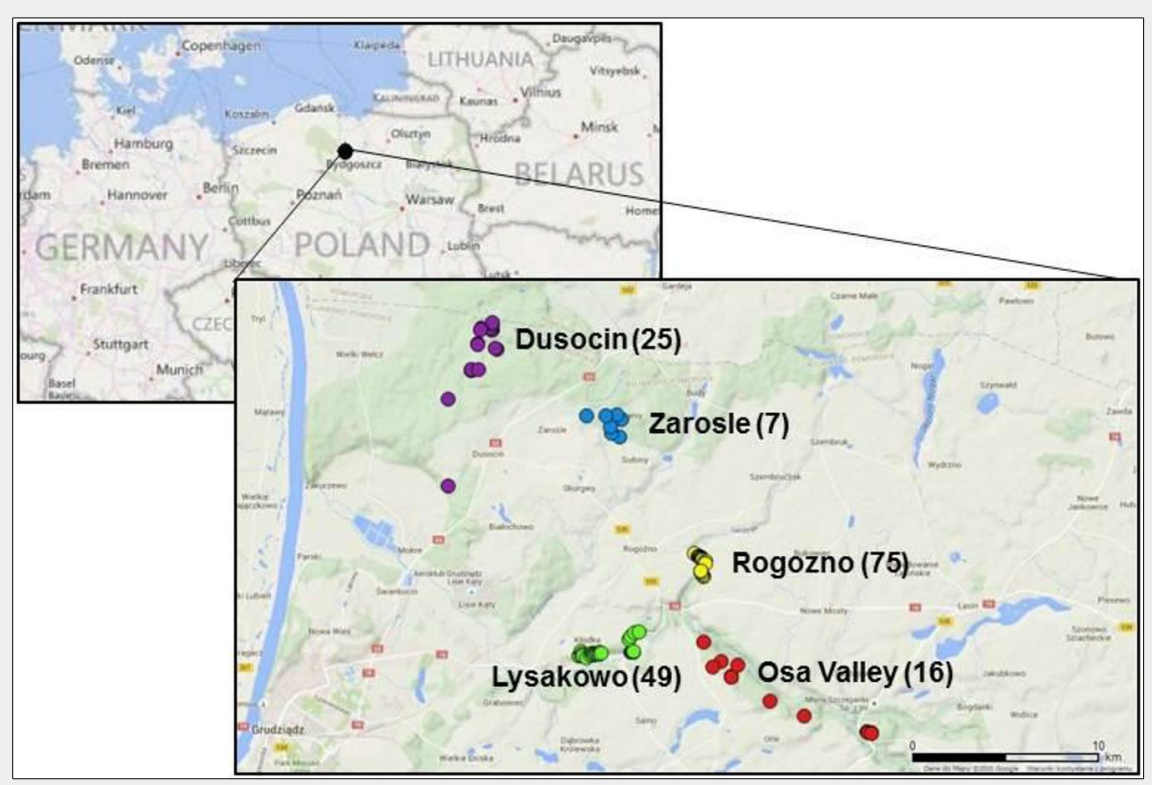

Fig. 1 - Distribution of populations of Sorbus torminalis at the north-eastern range limit. Populations are indicated by different colours and the numbers in parentheses indicate the population size (number of trees - Tab. 1).
Although several studies report on the genetic diversity of $\mathrm{S}$. torminalis populations throughout Europe (Demesure et al. 2000, Oddou-Muratorio et al. 2001a, Hoebee et al. 2006, Angelone et al. 2007, Belletti et al. 2007), studies focusing on peripheral populations of the species are scarce (Rasmussen \& Kollmann 2007b). The latter authors found that small populations located at the northern limits were characterized by high clonality and low genetic variation (Rasmussen \& Kollmann 2007b).

In this paper we investigated a group of small, fragmented populations of the wild service tree growing at the north-eastern species distribution limits. Using nuclear microsatellite markers, we assess the extent of clonality and the levels of genetic diversity. We also investigated the genetic structure within and among the studied populations. The results are discussed in the context of the management of genetic resources of the species.

\section{Materials and methods}

\section{Plant material sampling}

We sampled plants of Sorbus torminalis throughout populations located in the Forest District Jamy (Poland), which is the north-eastern range limit of the species $\left(18^{\circ} 51^{\prime}-19^{\circ} 00^{\prime} \mathrm{N}, 53^{\circ} 29^{\prime}-53^{\circ} 35^{\prime} \mathrm{E}\right)$. These populations have been previously described in detail by Bednorz (2004), who documented 203 adult trees in this region. We attempted to investigate all adult individuals (DBH $>10 \mathrm{~cm}$ ) growing in this area, however, in 2012 we could only locate 172 living trees, which were sampled for this study. All the sampled individuals were grouped into 5 spatially distinct populations (Tab. 1, Fig. 1). Rogozno and Lysakowo were the largest populations, consisting of 75 and 49 individuals, respectively. They were located along the edges of steep river valleys, mostly of southern exposure. The Zarosle and Osa Valley populations were distinctly smaller ( 7 and 16 individuals, respectively) and were located on a relatively flat area. The population Dusocin ( 25 trees) consisted of isolated individuals or small groups of trees $(<5)$ growing usually on small forest hills (Bednorz 2004, Tarnawski 2001). Each sampled individual was georeferenced using GPS mapping system Pathfinder ${ }^{\circledR}$ ProXT $^{\mathrm{TM}}$ (Trimble, Sunnyvale, USA) and the resulting data were visualized using the QGIS 2.8.2 free software (http://www.qgis.org/en/site/).

\section{Laboratory analyses}

Total genomic DNA from $30 \mathrm{mg}$ of dried leaf tissue was extracted according to the CTAB method (Doyle \& Doyle 1990), after grinding frozen tissue with Mixer Mill (MM301, Retsch, Haan, Germany). We screened all samples for variation at thirteen nuclear microsatellite markers: Sa01, Sa07, Sa14 (González-González et al. 2010); Mss1, Mss4, Mss5, Mss6, Mss9, Mss13, Mss16 
(Oddou-Muratorio et al. 2001b); CH01ho1 (Gianfranceschi et al. 1998); CHo2co9, Ms14Ho3 (Liebhard et al. 2002). Two PCR multiplexes were designed and optimized including six (multiplex-l: Chorho1, Cho2co9, Mss4, Sa01, Sa07, Sa14) and seven loci (multiplex-II: Ms14H03, Mss1, Mss5, Mss6, Mss9, Mss13, Mss16). Details about the primers are presented in the Supplementary material (Tab. S1). The PCR mixture (10 $\mu \mathrm{l}$ in volume) consisted of $10 \mathrm{ng}$ of template DNA, $1 \times$ of Multiplex PCR master mix (Qiagen), $0.5 \mathrm{mg} / \mathrm{ml} \mathrm{BSA}$, primers and water (Tab. S2 in Supplemetary material). Touch-down PCR was employed with cycling of $95{ }^{\circ} \mathrm{C}$ for 15 min followed by: 10 cycles of $94^{\circ} \mathrm{C}$ for $30 \mathrm{~s}, 60^{\circ} \mathrm{C}$ for $90 \mathrm{~s}$ with a reduction in temperatures of $0.5{ }^{\circ} \mathrm{C}$ per cycle, $72{ }^{\circ} \mathrm{C}$ for $60 \mathrm{~s}$; then 25 cycles of $94{ }^{\circ} \mathrm{C}$ for $30 \mathrm{~s}, 55^{\circ} \mathrm{C}$ for $90 \mathrm{~s}, 72{ }^{\circ} \mathrm{C}$ for $60 \mathrm{~s}$; and a final cycle of $72{ }^{\circ} \mathrm{C}$ for 10 min. PCR reaction was conducted with $\mathrm{PTC} 200^{\circledR}$ thermal cycler (MJ Research Inc., St. Bruno, Quebec, Canada). PCR products were sized using a capillary sequencer $A B I$ PRISM $3130 \mathrm{XL}^{\oplus}$ (Applied Biosystems, Foster City, (A, USA). Allele calling was performed using GENESCAN 3.7 and GENOTYPER 3.7 software provided by Applied Biosystems. Allele binning was done manually after plotting of fragment size distributions for each locus (Guichoux et al. 2011).

\section{Statistical analyses}

Genotypes of individual trees were analyzed for the presence of replicates (ramets within a clone) using the Identity Analysis option of the CERVUS program v. 3.0.3 (Kalinowski et al. 2007). Individuals with the same genotypes or with genotypes differing at one or two alleles were considered to belong to the same clone or genet (multi-locus lineage, MLL - Arnaud-Haond et al. 2007), and such one or two allele differences within MLLs were considered to be the results of somaclonal mutations. Clonal diversity $(\mathrm{G} / \mathrm{N})$, clonal richness $[R=$ $(\mathrm{G}-1) /(\mathrm{N}-1)]$ and the extent of clonality $(1-R)$ were calculated according to ArnaudHaond et al. (2007), being $G$ the number of genets and $N$ the number of individual trees sampled. For subsequent population genetic analyses, only one genotype per clone was considered, regardless of the number of ramets within a clone. The consensus (most frequent) genotype within a genet was considered as representative for a given MLL.

Standard population genetic parameters were estimated for each locus, including: number of alleles $(A)$, effective number of alleles $\left(A_{e}\right)$, allelic richness $(A R)$, observed $\left(H_{0}\right)$ and expected $\left(H_{\mathrm{e}}\right)$ heterozygosity. The loci were also tested for the presence of null alleles, with their frequencies estimated jointly with $F_{15}$ (Wright's fixation index) using the IIM approach in INEST 2.0 software (Chybicki \& Burczyk 2009). Genetic differentiation between populations was assessed by estimating $F_{\text {ST }}$ and $R_{\text {ST }}$ with FSTAT v. 2.9.3.2 software (Goudet 1995).
We used two procedures to infer genetic structure of the studied populations. First, we performed the spatial mixture analysis with correlated allele frequencies implemented in BAPS v. 6 software (Corander \& Marttinen 2006, Corander et al. 2008). We used an admixture model based on mixture clustering, and ran the analyses for 1000 iterations, setting the maximum possible number of subpopulations from 1 to 10. Second, we used a model-based clustering algorithm implemented in the STRUCTURE v. 2.3.4 software (Pritchard et al. 2000, Falush et al. 2003, 2007) to determine the number of subpopulations (K). We ran STRUCTURE using the default model parameters and varying $K$ from 1 to 10 . Each run consisted of 50,000 burn-in iterations and 100,000 data collection iterations, and was replicated 10 times. The number of clusters that best describes the data structure was found based on $\Delta \mathrm{K}$ statistics (Evanno et al. 2005) using the software package STRUCTURE HARVESTER (Earl \& Von Holdt 2012).

Spatial genetic structure (SGS) within populations was investigated using the package SPAGeDi v. 1.4 (Hardy \& Vekemans 2002). Due to small sample sizes within the populations, the SGS analysis was done for all populations jointly; however, only within populations pair-wise comparisons were allowed. The coordinates of a genet were determined as the arithmetic mean of coordinates of all individuals belonging to a given genet. The kinship coefficients $\left(F_{i j}\right.$ Loiselle et al. 1995) between pairs of individuals (or genets) were computed relative to local (within population) allele frequencies as suggested by Wang (2011), and they were regressed on the logarithm of spatial distance to estimate the logarithmic regression slope $b_{\log }$. The significance of $b_{\log }$ was tested based on 10,000 permutations of spatial positions of individuals within populations. The extent of SGS was estimated using the $S p$ statistic following Vekemans \& Hardy (2004). Sp was quantified by $S p=b_{\log } /[1 F(10, m)]$, where $b_{\text {log }}$ is the regression slope and $F(10, m)$ is the mean kinship coefficient between individual pairs within the first distance class (0-10 m).

We used the ML-RELATE computer program (Kalinowski et al. 2006) to infer sibling relationships among individual genotypes. This analysis was performed for the whole population jointly, and separately for each population and each cluster identified with BAPS software. We estimated the numbers of parent-offspring, full-sib and half-sib relationships in each group.

\section{Results}

\section{Clonal structure}

The 172 ramets $(N)$ screened for variation at 13 nSSR loci were found to cluster into 118 unique multilocus genotypes. However, in a few cases individual genotypes differed by only one (15 cases) or two alleles (3 cases). Individuals with genotypes differ- ing at one or two alleles were considered to belong to the same clone (multi-locus lineage, MLL - Arnaud-Haond et al. 2007), which suggested the existence of 100 clones $(G)$ in the study area $(G / N=0.58-$ see Tab. $\mathrm{S}_{3}$ in Supplementary material). Thus approximately $42 \%$ of trees belonged to clonal groups. For subsequent genetic analyses the consensus (most frequent) genotype was considered as a representative one for a given MLL (or genet).

The distribution of clonality was not uniform among populations (Tab. 1). There was no evidence of clonality in Zarosle, only one clonal group in Osa Valley (4 ramets) and just four clonal groups (2-3 ramets per clone) in Dusocin. In contrast, clonality was extensive in Rogozno and Lysakowo (12 and 8 clonal groups, respectively). In all cases, ramets of the same clone were growing in close proximity.

There was a strong correlation between the number of individual trees and the number of MLLs per population $(r=0.918$, $p=0.028$ ). The number of individual trees and the number of MLLs were significantly correlated $(p<0.05)$ to all clonal measures (number of clonal groups, clonal richness, extent of clonality). For example, the number of clonal groups within population was tightly correlated to the number of individual trees $(r=0.994, p<0.001)$.

Notably, the largest clone was found in Rogozno and was composed by 17 individual trees (ramets), with DBH ranging from 7 to $17 \mathrm{~cm}$. The distance between the most remote individuals within this clone was found to be 21 meters. Interestingly, the tree considered as the largest wild service tree in Poland $(\mathrm{DBH}=70 \mathrm{~cm})$ growing in Dusocin (Bednorz 2004) appeared to be just one of the three ramets of a clone, indicating that the individual as a genet is even larger in size than previously considered.

\section{Somaclonal variation}

Comparing genotypes within each MLL, we found 20 cases of allelic differences observed within 16 MLLs. These differences were considered as the effect of somaclonal mutation. When mutated genotypes were compared with consensus genotypes within MLL, the mutation usually affected a larger allele of a pair of alleles within a locus of a given individual ( 16 cases), with only 4 cases of a smaller allele being mutated. The mutations resulted usually in an increase of the fragment size, with the changed allele being on average greater by 2 bp (one repeat unit), as compared to the consensus one. Somaclonal variation was noted in 6 out of 13 loci. The largest number of mutations (10) was observed in locus Mss16. The overall frequency of mutations measured within MLLs was 0.0084 (or 0.0045 when excluding the locus Mss16), with the most variable locus Mss16 having the mutation frequency of 0.0544 . 
Tab. 2 - Genetic diversity of the whole population of Sorbus torminalis in the Forest District Jamy, Poland. $(A)$ : mean number of alleles; $\left(A_{e}\right)$ : effective number of alleles; $(A R)$ : allelic richness; $\left(H_{\mathrm{o}}\right)$ : observed heterozygosity; $\left(H_{\mathrm{e}}\right)$ : expected heterozygosity; $\left(F_{i s}\right)$ : inbreeding coefficient; (Null): frequency of null alleles; $(H-W)$ : significance of departure from Hardy-Weinberg equilibrium; (ns): not significant ( $p>0.05)$.

\begin{tabular}{lrrrlllll}
\hline Locus & \multicolumn{1}{c}{$\boldsymbol{A}$} & \multicolumn{1}{c}{$\boldsymbol{A}_{\mathrm{e}}$} & \multicolumn{1}{c}{$\boldsymbol{A} \boldsymbol{R}$} & $\boldsymbol{H}_{\mathrm{o}}$ & $\boldsymbol{H}_{\mathrm{e}}$ & \multicolumn{1}{l}{$\boldsymbol{F}_{\text {is }}$} & Null & $\boldsymbol{H}-\boldsymbol{W}$ \\
\hline Ch01h01 & 10 & 6.974 & 9.980 & 0.850 & 0.855 & 0.006 & 0 & $\mathrm{~ns}$ \\
\hline Ch02c09 & 8 & 4.296 & 8.000 & 0.900 & 0.766 & -0.176 & 0 & $\mathrm{~ns}$ \\
\hline Mss4 & 4 & 2.218 & 4.000 & 0.610 & 0.625 & 0.024 & 0.014 & $\mathrm{~ns}$ \\
\hline Sa01 & 12 & 5.663 & 11.979 & 0.730 & 0.805 & 0.093 & 0.023 & $\mathrm{~ns}$ \\
\hline Sa07 & 5 & 2.483 & 5.000 & 0.667 & 0.605 & -0.101 & 0 & $\mathrm{~ns}$ \\
\hline Sa14 & 18 & 4.000 & 17.969 & 0.820 & 0.764 & -0.074 & 0 & $\mathrm{~ns}$ \\
\hline Ms14H03 & 7 & 3.804 & 6.990 & 0.730 & 0.724 & -0.008 & 0 & $\mathrm{~ns}$ \\
\hline Mss1 & 9 & 3.865 & 7.980 & 0.760 & 0.738 & -0.030 & 0.013 & $\mathrm{~ns}$ \\
\hline Mss13 & 7 & 2.473 & 6.980 & 0.620 & 0.600 & -0.034 & 0 & $\mathrm{~ns}$ \\
\hline Mss16 & 19 & 11.614 & 18.979 & 0.930 & 0.923 & -0.008 & 0 & $\mathrm{~ns}$ \\
\hline Mss5 & 10 & 5.701 & 9.990 & 0.830 & 0.817 & -0.016 & 0 & $\mathrm{~ns}$ \\
\hline Mss6 & 10 & 4.829 & 9.980 & 0.830 & 0.784 & -0.059 & 0 & $\mathrm{~ns}$ \\
\hline Mss9 & 17 & 6.588 & 15.980 & 0.830 & 0.817 & -0.016 & 0.006 & $\mathrm{~ns}$ \\
\hline Mean & 10 & 4.939 & 10.293 & 0.777 & 0.756 & -0.029 & 0.004 & - \\
SE & 1.338 & 0.762 & 1.315 & 0.028 & 0.027 & 0.018 & 0.002 & - \\
\hline
\end{tabular}

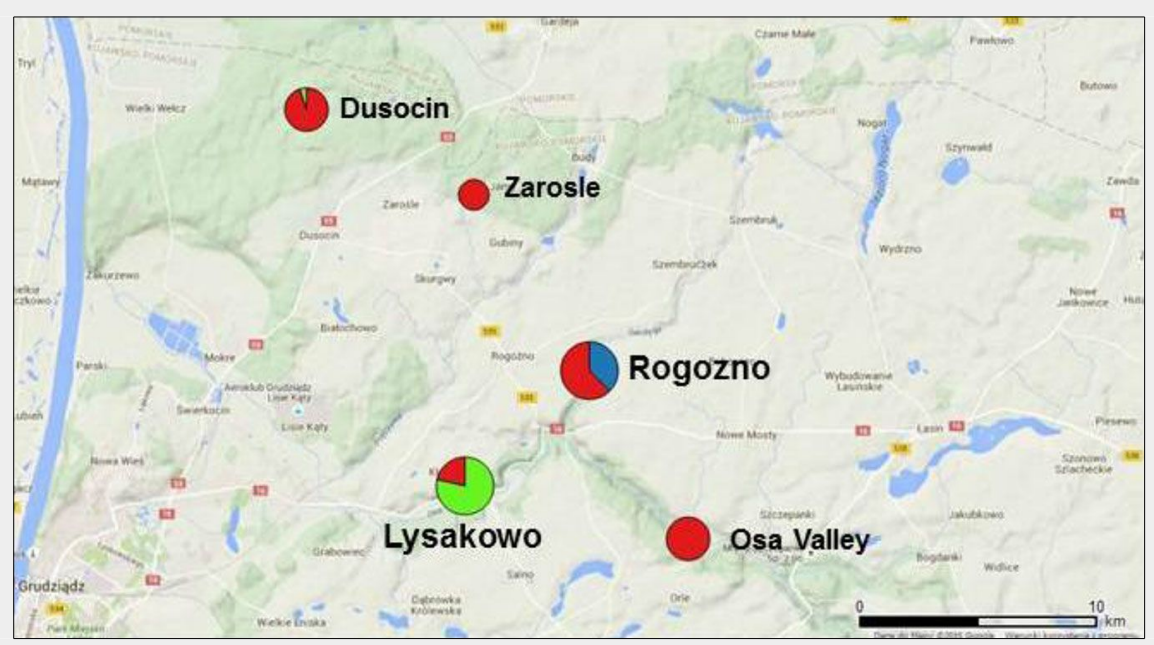

Fig. 2 - Spatial distribution of clusters identified using the BAPS software (cluster 1: red; cluster 2: green; cluster 3: blue). The size of the circles is proportional to the number of clones within population (Tab. 1).

Tab. 3 - Probabilities of relationships for different populations and clusters identified with BAPS software, estimated based on pairs of individuals.

\begin{tabular}{llcccccc}
\hline Group & Pop & $\begin{array}{c}\text { Sample } \\
\text { size }\end{array}$ & $\begin{array}{c}\text { Full sibs } \\
(\%)\end{array}$ & $\begin{array}{c}\text { Half sibs } \\
(\%)\end{array}$ & $\begin{array}{c}\text { Full + Half } \\
\text { sibs (\%) }\end{array}$ & $\begin{array}{c}\text { Parent/ } \\
\text { Offspring } \\
(\%)\end{array}$ & $\begin{array}{c}\text { Unrelated } \\
(\%)\end{array}$ \\
\hline Population & Dusocin & 19 & 1.2 & 9.3 & 10.5 & 0 & 89.5 \\
& Zarosle & 7 & 0 & 0 & 0 & 0 & 100.0 \\
& Rogozno & 30 & 1.8 & 6.2 & 8.0 & 3.7 & 88.3 \\
& Lysakowo & 31 & 3.4 & 10.8 & 14.2 & 4.1 & 81.7 \\
& Osa Valley & 13 & 2.6 & 5.1 & 7.7 & 3.8 & 88.5 \\
& Mean & 20.0 & 1.8 & 6.3 & 8.1 & 2.3 & 89.6 \\
\hline BAPS & 1 & 68 & 0.6 & 11.1 & 11.7 & 0.6 & 87.7 \\
cluster & 2 & 23 & 5.1 & 9.9 & 15.0 & 4.3 & 80.7 \\
& 3 & 9 & 2.8 & 22.2 & 25.0 & 11.1 & 63.9 \\
& Mean & 33.3 & 2.8 & 14.4 & 17.2 & 5.3 & 77.5 \\
\hline \multirow{4}{*}{ All } & Total & 100 & 1.3 & 11.7 & 13.0 & 0.9 & 86.1 \\
\hline
\end{tabular}

\section{Genetic diversity}

Genetic diversity parameters were calculated based on the consensus genotypes established for each clone. Thus, the analyses of genetic diversity and populations structure were calculated based on a set of 100 distinct genotypes. All 13 microsatellite loci appeared to be polymorphic with the number of alleles at each locus ranging from 4 to 19, with a mean of 10 (Tab. 2). Average effective number of alleles was equal to 4.939. Average observed and expected heterozygosities were found to be 0.777 and 0.756 , respectively. Wright's fixation index $\left(F_{i s}\right)$ was found to be -0.029 , indicating a small excess of heterozygotes. A detectable proportion of null alleles was found at loci Mss4, Sa01, Mss1 and Mss9, but in all cases they were not significantly different from o. No deviations from HardyWeinberg equilibrium were found at any locus.

\section{Genetic structure (clustering)}

The differentiation among populations was rather low with average $F_{\mathrm{ST}}=0.0477 \pm$ $0.0058(\mathrm{SE})$ and $R_{\mathrm{ST}}=0.0588 \pm 0.0100$. We found no relationship between genetic distance among pairs of populations measured as $F_{S T} /\left(1-F_{S T}\right)$ and their physical distance quantified as logarithm of distance. However, both BAPS and STRUCTURE clustering methods identified three distinct clusters as the most likely structure of the analyzed data set. Notably, there was a high congruence between the two methods, since $90 \%$ of genets were assigned to the same clusters in each of the clustering methods (Fig. 2). Therefore, we present below only the result of clustering identified with BAPS software.

The smallest cluster (cluster 3 - Tab. 3) was composed of 9 genets only. It appeared to be spatially restricted and fully included in the population Rogozno. Cluster 2 consisted of 22 individuals from population Lysakowo and one isolated remote individual assigned to population Dusocin. All the remaining 68 genets were grouped into the largest cluster 1. Although, the cluster 1 was spread across all populations, the cluster 2 and 3 were spatially restricted.

\section{Spatial genetic structure within populations}

We found evidence of spatial genetic structure within populations. Pairwise kinship coefficients appeared to be significant for pairs of individuals separated up to about 100 meters (Fig. 3). The slope of the regression of the kinship coefficient on the logarithm of spatial distance between genets was found to be $b_{\log }=-0.012(p<0.001)$. The Sp statistic was 0.0125 , indicating a weak but significant fine-scale pattern of isolation by distance.

\section{Relatedness}

The levels of relatedness varied among populations. There was no relatedness among individuals in the population of $\mathrm{Za}$ - 
Fig. 3 - Autocorrelogram of estimated kinship coefficients $\left(F_{i i j}\right)$ against the logarithm of distance. Upper and lower $95 \%$ confidence intervals around the null distribution of kinship coefficients derived from 10,000 permutations are indicated by shaded area. Black bars around $F_{i j}$ values represent standard errors obtained by a jackknife procedure over loci.

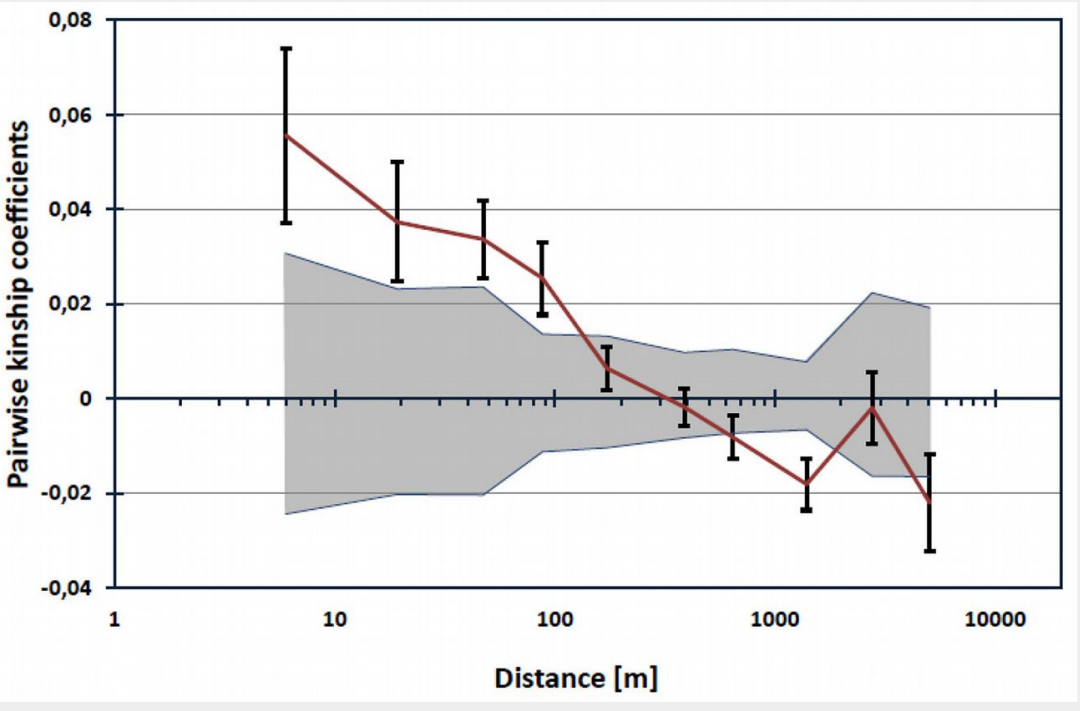

rosle, which is composed of scattered individuals only. The highest level of relatedness in all categories was found in Lysakowo (Tab. 3). Other populations exhibited intermediate and comparable levels of relatedness (Tab. 3), however, we found no indication of parent / offspring relationships in Dusocin. When considering clusters of individuals identified with BAPS software, the highest level of relatedness was found in the cluster 3, where only $64 \%$ pair-wise comparisons indicated lack of relatedness. However, this cluster is relatively small (9 MLLs) and spatially restricted, and belongs to the population Rogozno (Fig. 3). The largest cluster (No. 1) composed of $68 \mathrm{MLLs}$, embracing individuals from every population, exhibited the lowest level of relatedness (Tab. 3). The remaining cluster 2 , being the spatially restricted part of the population Lysakowo (Fig. 3), had the largest proportion of fullsib relationships, and the proportion of pairwise comparisons - indicating lack of relatedness - was found to be $80.7 \%$. It should be noted that we found generally positive correlations between the number of MLLs and relatedness measures, but they appeared to be insignificant, likely due to a small number (5) of compared populations (e.g., proportion of fullsibs + halfsibs: $r=0.788, p=0.114$ ).

\section{Discussion}

Mapping genetic diversity and structure in marginal plant populations is essential for managing their genetic resources. This is particularly important for rare, scattered tree species, such as Sorbus torminalis. For example, such knowledge allows to design seed sampling for ex-situ and in-situ conservation efforts (selection of populations and spacing among sampled trees) maximizing genetic diversity of future generations. Because $S$. torminalis has the ability for vegetative reproduction and clonal growth (Hoebee et al. 2006, Rasmussen \& Kollmann 2007b), population genetic surveys of this species should be conducted with careful assessment of the presence of clones, which should be taken it into account in subsequent genetic analyses (Arnaud-Haond et al. 2007). This is particularly important in Sorbus species and other members of the Rosaceae family, which are known for their capacity for clonal propagation through rootsuckers (Nagamitsu et al. 2004, Rasmussen \& Kollmann 2004, Hoebee et al. 2006, Rasmussen \& Kollmann 2007a, Vaughan et al. 2007, Jolivet \& Degen 2011).

Clonality in plants is often considered as an effective strategy for survival and the maintenance of existing genetic diversity of populations during harsh environmental conditions or during colonization of new areas where sexual reproduction is limited (Vallejo-Marín et al. 2010). This strategy seems to be particularly useful in plants with self-incompatibility systems. Vegetative propagation may continue until mating among unrelated individuals becomes possible, producing new generations of variable offspring cohorts (Vallejo-Marín et al. 2010).

We found the mean number of ramets per genet (1.72 - Tab. 1) quite comparable to that reported for other populations across the northern range of this species (Oddou-Muratorio et al. 2004, Hoebee et al. 2006, Rasmussen \& Kollmann 2007b). The distribution of clonality among populations investigated in this study, however, was not uniform. Clones were more frequent in populations growing on rugged areas, such as steep river valleys or mid-forest hills. Fairly extensive clonality was noted in peripheral northern populations growing at the Baltic coast of Denmark and Germany, with on average 2.64 ramets per genet (Rasmussen \& Kollmann 2007b). On the other hand, 2.26 ramets per genotype were found in Switzerland, but there were populations with some clones represented by more than 10 ramets (Hoebee et al. 2006). Other authors reported only scarce examples of clonality. For instance, only few stems over 185 individuals were found to be the result of vegetative reproduction in a French population of S. torminalis (Oddou-Muratorio et al. 2004). Some studies may underreport the natural incidence of clonality because they were specifically designed to avoid sampling from the same genets, which prevented precise estimation of the extent of clonality (Belletti et al. 2007).

Somatic mutations are increasingly recognized as an inevitable feature in clonally reproducing plants and long-lived tree species (Mock et al. 2008, Gross et al. 2012, James \& McDougall 2014). Somatic mutations result in minor DNA variation within clonal lineages (James \& McDougall 2014) and it is suggested that old clones may accumulate somatic mutations to a greater extent (Wyman et al. 2003, Tuskan et al. 2006, Mock et al. 2008). Understanding the development of somaclonal variation requires closer attention because older and slowly-growing clones could have levels of mutations similar to those of younger, faster-growing clones, as the mutation rate is expected to be proportional to the number of mitotic divisions (Klekowski 2003, Ally et al. 2008, 2010, James \& McDougall 2014). As somatic mutations accumulate in clones, the remaining stems may appear to be genetically distinct clones. Somatic mutation at microsatellite loci have been observed in the Rosaceae family: Prunus ssiori (Nagamitsu et al. 2004), P. avium (Vaughan et al. 2007), but also in other plants: Fragaria virginiana (Wilk et al. 2009), Grevillea renwickiana, (James \& McDougall 2014), G. rhizomatosa (Gross et al. 2012), including tree species: Robinia pseudoacaccia (Lian et al. 2004), Populus euphratica (Schnittler \& Eusemann 2010), Populus tremuloides (Mock et al. 2008), Quercus robur (Bakker et al. 2001), Quercus ilex (Ortego et al. 2010), Thuja plicata (O'Connell \& Ritland 2004). Somaclonal variation of microsatellite loci may confound the inference of clonal structure (Arnaud-Haond et al. 2007), but usually a careful assessment of allelic variation 
among putative ramets of the same clone enable the proper assignment of specimens to respective clones, thus establishing multi-locus lineages (MLLs - ArnaudHaond et al. 2007, Vaughan et al. 2007). The somaclonal variation detected in this paper (i.e., most frequent allele change of one 2-bp microsatellite repeat unit) seem to be in line with the expected microsatellite mutation models (Estoup et al. 2002).

Although we found extensive clonality of S. torminalis, we also found relatively high levels of genetic diversity across the surveyed region. This contrasts the results of a study on $\mathrm{S}$. torminalis populations growing at the northern range limit by Rasmussen \& Kollmann (2007b), who found extensive clonality and low genetic diversity. The authors also observed high genetic differentiation among populations $\left(F_{\mathrm{ST}}=0.341\right)$, which was partly attributed to extensive clonality and genetic drift. Our results showed similar numbers of alleles per locus as reported in more central populations of France (Oddou-Muratorio et al. 2001b) and Switzerland (Kamm et al. 2009) and higher genetic diversity than that observed in $\mathrm{S}$. domestica across Europe (George et al. 2015).

Inbreeding coefficients of $S$. torminalis are usually found to be slightly negative, indicating excess of heterozygotes as compared to expectations from Hardy-Weinberg equilibrium (Bednorz et al. 2006, Hoebee et al. 2007). Our results confirmed this finding with inbreeding coefficients being consistently slightly negative across almost all SSR loci. This is reasonable given the self-incompatibility mating system of the species (Ludwig et al. 2013, Stoeckel et al. 2006); however, asexual reproduction may also affect $F_{15}$ estimates (Stoeckel \& Masson 2014).

Although genetic diversity is expected to decrease towards species distribution margins (Eckert et al. 2008), there are several examples where genetic diversity within populations did not decline towards range margins, but an increase of population differentiation was observed (Yakimowski \& Eckert 2008, Wagner et al. 2011, Assis et al. 2013). This may be particularly relevant for S. torminalis. Kučerová et al. (2010) found higher differentiation over central-European populations than those located in southern locations. Genetic differentiation among populations investigated in this study was found to be low, as compared to other studies (Demesure et al. 2000, Bednorz et al. 2006, Angelone et al. 2007, Kučerová et al. 2010), which might be attributed to close proximity of the populations under study. The $F_{S T}$ and $R_{S T}$ estimates were quite similar $\left(F_{\mathrm{ST}}=0.048 \pm 0.006\right.$ and $R_{\mathrm{ST}}=$ $0.059 \pm 0.010)$, indicating that the differentiation was not caused by mutation, but rather it was due to specific colonization and gene flow patterns among populations (Balloux \& Lugon-Moulin 2002).

With the climate changes predicted in the future, S. torminalis is expected to extend its range towards northern and eastern locations (Ozolinčius et al. 2013). The studied populations with their high genetic diversity may thus become an important source of genetic diversity for natural or assisted expansion of the species into new areas where climate conditions will become more favorable (Kramer \& Havens 2009).

Genetic structure among populations based on Bayesian clustering methods revealed only moderate population structuring, which seems to be in line with the assessment of among population differentiation. However, we identified significant spatial genetic structure within populations, indicating that at a local scale, isolation by distance may be an important mechanism shaping the distribution of genetic diversity (Fig. 3). The spatial genetic structure parameter Sp (Vekemans \& Hardy 2004), was found to be $S p=0.0125$, and it appeared similar to that reported in a French population $(\mathrm{Sp}=0.0187)$ by Oddou-Muratorio \& Klein (2008). However, spatial genetic structure was not found in Swiss populations (Hoebee et al. 2006). Our results are generally in line with the expectations for clonal insect pollinated and animal seed-dispersed species, as recently reviewed by Dering et al. (2015).

Genetic diversity in peripheral populations may be determined by locally specific factors such as the history of colonization and local population dynamics (e.g., expansion or shrinkage). The spatial distribution of genetic variation observed in this study seems to be the result of specific pattern of colonization of the studied area, as revealed by the distribution of relatedness among populations or groups identified by clustering methods (Tab. 3). However, the subsequent populations expansion could have led to the existing within-population spatial genetic structure. The relatively high genetic diversity of the populations seems to be maintained by efficient gene dispersal coupled with a self-incompatibility mating system (Hoebee et al. 2006, Angelone et al. 2007,). Indirect estimates of relative pollen to seed gene dispersal in $S$. torminalis have been found to be low (1.842.92 - Angelone et al. 2007, Oddou-Muratorio \& Klein 2008), indicating the importance of seed dispersal in shaping the genetic diversity in this species. Efficient pollen and seed dispersal over distances greater than $10 \mathrm{~km}$ have been detected in S. domestica, a species with similar pollination and seed dispersal biology (Kamm et al. 2009), suggesting that fragmented populations, such as those investigated in this study, may nonetheless be genetically connected by gene flow.

Our study demonstrated that peripheral populations of S. torminalis may have relatively high levels of genetic diversity, despite the occurrence of clonal propagation. The studied populations demonstrated low genetic differentiation and lack of inbreeding. However, the existence of clonality and signatures of spatial genetic structure should be taken into consideration when planning seed harvesting of this protected species for future conservation genetic programs in the studied area and in other similar populations. Avoiding sampling seeds from nearby trees, likely related or being even ramets of the same clone, should promote high genetic diversity of resulting progeny generations.

The frequency of clonal versus sexual reproduction across the range of $\mathrm{S}$. torminalis is not fully characterized, but population surveys done to date suggest that the predominant mode of reproduction within a population changes across the species range. The propensity for clonal reproduction is likely to be determined by local (e.g., topography) conditions, although the factors influencing the tendency for clonal versus sexual reproduction are unknown. Because the extent of clonal reproduction varies between populations of S. torminalis, it is very likely that the spatial genetic structure within and among populations will also vary. An effective management strategy for this species should incorporate the variability in reproductive biology of this species and thus requires a broader survey of the genetic variation spanning over the species' range.

\section{Acknowledgements}

We thank Dr. Magdalena Bartkowska for valuable comments and suggestions, which significantly improved the paper. The study was supported by the National Science Center, Poland (Grant No: 2011/03/ B/NZ9/03139). Plant material was sampled based on the permission WPN.6402.1.13. 2011.WR issued by the Regional Directorate for Environmental Protection in Bydgoszcz, Poland. The authors are thankful to Igor Chybicki for his help in collecting samples in the field. Local support and field guidance by Andrzej Tarnawski and Tadeusz Kempa from the Directorate of Forest District Jamy is greatly acknowledged.

SJ-W and JB planned the research, contributed to statistical analyses and wrote the article; SJ-W, KM and ES designed and optimized PCR multiplexes and performed laboratory analyses; LK and JB designed the sample collection and sampled the plant material; JB obtained funding.

\section{References}

Ally D, Ritland K, Otto S (2008). Can clone size serve as a proxy for clone age? An exploration using microsatellite divergence in Populus tremuloides. Molecular Ecology 17: 4897-4911. doi: 10.1111/j.1365-294X.2008.03962.x

Ally D, Ritland K, Otto SP (2010). Aging in a longlived clonal tree. PLoS Biology 8: e1000454. doi: 10.1371/journal.pbio.1000454

Angelone S, Hilfiker K, Holderegger R, Bergamini A, Hoebee S (2007). Regional population dynamics define the local genetic structure in Sorbus torminalis. Molecular Ecology 16: 1291-1301. - doi: 10.1111/j.0962-1083.2006.03202.x

Arnaud-Haond S, Duarte CM, Alberto F, Serrao 
EA (2007). Standardizing methods to address clonality in population studies. Molecular Ecology 16: 5115-5139. - doi: 10.1111/j.1365-294X.2007. 03535.x

Assis J, Castilho Coelho N, Alberto F, Valero M, Raimondi P, Reed D, Serrao EA (2013). High and distinct range-edge genetic diversity despite local bottlenecks. PloS ONE 8: e68646. - doi: 10.1371/journal.pone.0068646

Bakker EG, Van Dam BC, Van Eck HJ, Jacobsen E (2001). The description of clones of Quercus robur L. and Q. petraea (Matt.) Liebl. with microsatellites and AFLP in an ancient woodland. Plant Biology 3: 616-621. - doi: 10.1055/s-200119365

Balloux F, Lugon-Moulin N (2002). The estimation of population differentiation with microsatellite markers. Molecular Ecology 11: 155-165. doi: 10.1046/j.0962-1083.2001.01436.x

Bednorz L (2004). Rozmieszczenie i zasoby Sorbus torminalis (Rosaceae: Maloideae) w Polsce [Distribution and resources of Sorbus torminalis (Rosaceae: Maloideae) in Poland]. Fragmenta Floristica et Geobotanica Polonica 11: 105-121. [in Polish]

Bednorz L (2007). Conservation of genetic resources of Sorbus torminalis in Poland. Dendrobiology 58: 3-7. [online] URL: http://agro.icm. edu.pl/agro/element/bwmeta1.element.agro-ar ticle-8ebe0401-9716

Bednorz L, Myczko L, Kosinski P (2006). Genetic variability and structure of the wild service tree (Sorbus torminalis (L.) crantz) in Poland. Silvae Genetica 55: 197-202. [online] URL: http:// www.germanjournalofforestresearch.com/filea dmin/content/dokument/archiv/silvaegenetica/ 55_2006/55-4-5-197.pdf

Belletti P, Monteleone I, Ferrazzini D (2007). A population genetic study in a scattered forest species, wild service tree [Sorbus torminalis (L.) Crantz], using RAPD markers. European Journal of Forest Research 127: 103-114. - doi: 10.1007/ s10342-007-0187-1

Chybicki IJ, Burczyk J (2009). Simultaneous estimation of null alleles and inbreeding coefficients. Journal of Heredity 100: 106-113. - doi: 10.1093/jhered/esno88

Corander J, Marttinen P (2006). Bayesian identification of admixture events using multilocus molecular markers. Molecular Ecology 15: 28332843. - doi: 10.1111/j.1365-294X.2006.02994.X

Corander J, Marttinen P, Siren J, Tang J (2008). Enhanced Bayesian modelling in BAPS software for learning genetic structures of populations. BMC Bioinformatics 9: 539. - doi: 10.1186/14712105-9-539

Demesure B, Le Guerroue B, Lucchi G, Prat D, Petit RJ (2000). Genetic variability of a scattered temperate forest tree: Sorbus torminalis L. (Crantz). Annals of Forest Science 57: 63-71. doi: 10.1051/forest:2000101

Demesure-Musch B, Oddou-Muratorio S (2004). EUFORGEN technical guidelines for genetic conservation and use for wild service tree (Sorbus torminalis). Bioversity International, Rome, Italy, pp. 6. [online] URL: http://books.google. com/books?id=eTnP-BK54fkC

Dering M, Chybicki IJ, Raczka G (2015). Clonality as a driver of spatial genetic structure in populations of clonal tree species. Journal of Plant Research 128: 731-745. - doi: 10.1007/s10265-015-
0742-7

Doyle JJ, Doyle JH (1990). Isolation of plant DNA from fresh tissue. Focus 12: 13-15.

Earl DA, Von Holdt BM (2012). STRUCTURE HARVESTER: a website and program for visualizing STRUCTURE output and implementing the Evanno method. Conservation Genetics Resources 4: 359-361. - doi: 10.1007/s12686-011-95 48-7

Eckert CG, Samis KE, Lougheed SC (2008). Genetic variation across species' geographical ranges: the central-marginal hypothesis and beyond. Molecular Ecology 17: 1170-1188. - doi: 10.1111/j.1365-294X.2007.03659.x

Ellstrand NC, Elam DR (1993). Population genetic consequences of small population-size - implications for plant conservation. Annual Review of Ecology and Systematics 24: 217-242. - doi: 10.1146/annurev.es.24.110193.001245

Estoup A, Jarne P, Cornuet JM (2002). Homoplasy and mutation model at microsatellite loci and their consequences for population genetics analysis. Molecular Ecology 11: 1591-1604. doi: 10.1046/j.1365-294X.2002.01576.x

Evanno G, Regnaut S, Goudet J (2005). Detecting the number of clusters of individuals using the software STRUCTURE: a simulation study. Molecular Ecology 14: 2611-2620. - doi: 10.1111/ j.1365-294X.2005.02553.x

Falush D, Stephens M, Pritchard JK (2003). Inference of population structure using multilocus genotype data: linked loci and correlated allele frequencies. Genetics 164: 1567-1587. [online] URL: http://www.genetics.org/content/164/4/15 67.short

Falush D, Stephens M, Pritchard JK (2007). Inference of population structure using multilocus genotype data: dominant markers and null alleles. Moleculat Ecology Notes 7: 574-578. - doi: 10.1111/j.1471-8286.2007.01758.x

García-Ramos G, Kirkpatrick M (1997). Genetic models of adaptation and gene flow in peripheral populations. Evolution 51: 21-28. - doi: 10.2307/2410956

George JP, Konrad H, Collin E, Thevenet J, Ballian D, Idzojtic M, Kamm U, Zhelev P, Geburek T (2015). High molecular diversity in the true service tree (Sorbus domestica) despite rareness: data from Europe with special reference to the Austrian occurrence. Annals of Botany 115 (7): 1105-1115. - doi: 10.1093/aob/mcv047

Gianfranceschi L, Seglias N, Tarchini R, Komjanc M, Gessler C (1998). Simple sequence repeats for the genetic analysis of apple. Theoretical and Applied Genetics 96 (8): 1069-1076. - doi: 10.1007/s001220050841

González-González EA, González-Pérez MA, Rivero E, Sosa PA (2010). Isolation and characterization of microsatellite loci in Sorbus aria (Rosaceae). Conservation Genetics Resources 2: 341-343. - doi: 10.1007/s12686-010-9238-x

Goudet J (1995). FSTAT (Version 1.2): A computer program to calculate F-statistics. Journal of Heredity 86: 485-486. [online] URL: http:// jhered.oxfordjournals.org/content/86/6/485.ex tract

Gross CL, Nelson PA, Haddadchi A, Fatemi M (2012). Somatic mutations contribute to genotypic diversity in sterile and fertile populations of the threatened shrub, Grevillea rhizomatosa (Proteaceae). Annals of Botany 109: 331-342. doi: $10.1093 / \mathrm{aob} / \mathrm{mcr} 283$

Guichoux E, Lagache L, Wagner S, Chaumeil P, Léger P, Lepais O, Lepoittevin C, Malausa T, Revardel E, Salin F, Petit R (2011). Current trends in microsatellite genotyping. Molecular Ecology Resources 11 (4): 591-611. - doi: 10.1111/j.17550998.2011.03014.x

Hardy OJ, Vekemans X (2002). SPAGEDi: a versatile computer program to analyse spatial genetic structure at the individual or population levels. Molecular Ecology Notes 2: 618-620. doi: 10.1046/j.1471-8286.2002.00305.x

Hedhly A, Hormaza JI, Herrero M (2009). Global warming and sexual plant reproduction. Trends in Plant Science 14: 30-36. - doi: 10.1016/j.tplan ts.2008.11.001

Hoebee SE, Menn C, Rotach P, Finkeldey R, Holderegger $R$ (2006). Spatial genetic structure of Sorbus torminalis: the extent of clonal reproduction in natural stands of a rare tree species with a scattered distribution. Forest Ecology and Management 226: 1-8. - doi: 10.1016/j.for eco.2005.12.024

Hoebee SE, Arnold U, Duggelin C, Gugerli F, Brodbeck S, Rotach P, Holderegger R (2007). Mating patterns and contemporary gene flow by pollen in a large continuous and a small isolated population of the scattered forest tree Sorbus torminalis. Heredity 99: 47-55. - doi: 10.1038/sj.hdy.6800962

James EA, McDougall KL (2014). Spatial genetic structure reflects extensive clonality, low genotypic diversity and habitat fragmentation in Grevillea renwickiana (Proteaceae), a rare, sterile shrub from south-eastern Australia. Annals of Botany 114: 413-423. - doi: 10.1093/aob/mcu 049

Jolivet C, Degen B (2011). Spatial genetic structure in wild cherry (Prunus avium L.): II. Effect of density and clonal propagation on spatial genetic structure based on simulation studies. Tree Genetics and Genomes 7: 541-552. - doi: 10.1007/s11295-010-0354-2

Jump AS, Marchant R, Penuelas J (2009). Environmental change and the option value of genetic diversity. Trends in Plant Science 14: 5158. - doi: 10.1016/j.tplants.2008.10.002

Kalinowski ST, Wagner AP, Taper ML (2006). MLrelate: a computer program for maximum likelihood estimation of relatedness and relationship. Molecular Ecology Notes 6: 576-579. - doi: 10.1111/j.1471-8286.2006.01256.x

Kalinowski ST, Taper ML, Marshall TC (2007). Revising how the computer program CERVUS accommodates genotyping error increases success in paternity assignment. Molecular Ecology 16: 1099-1106. - doi: 10.1111/j.1365-294X.2007. 03089.x

Kamm U, Rotach P, Gugerli F, Siroky M, Edwards P, Holderegger R (2009). Frequent long-distance gene flow in a rare temperate forest tree (Sorbus domestica) at the landscape scale. Heredity 103: 476-482. - doi: 10.1038/hdy.2009.70 Klekowski EJ (2003). Plant clonality, mutation, diplontic selection and mutational meltdown. Biological Journal of the Linnean Society 79: 6167. - doi: 10.1046/j.1095-8312.2003.00183.x

Koskela J, Buck A, Teissier du Cros E (2007). Climate change and forest genetic diversity: implications for sustainable forest management in Europe. Bioversity International, Rome, Italy, 
pp. 111. [online] URL: http://books.google.com/ books?id=9iycXkr5BgEC

Kramer AT, Havens K (2009). Plant conservation genetics in a changing world. Trends in Plant Science 14: 599-607. - doi: 10.1016/j.tplants.20 09.08 .005

Kučerová V, Honec M, Paule L, Zhelev P, Gömöry D (2010). Genetic differentiation of Sorbus torminalis in Eastern Europe as determined by microsatellite markers. Biologia 65: 817-821. doi: 10.2478/s11756-010-0082-y

Lesica P, Allendorf FW (1995). When are peripheral populations valuable for conservation? Conservation Biology 9: 753-760. - doi: 10.1046/ j.1523-1739.1995.09040753.X

Lian C, Oishi R, Miyashita N, Hogetsu T (2004). High somatic instability of a microsatellite locus in a clonal tree, Robinia pseudoacacia. Theoretical and Applied Genetics 108: 836-841. - doi: 10.1007/s00122-003-1500-0

Liebhard R, Gianfranceschi L, Koller B, Ryder CD, Tarchini R, Van De Weg E, Gessler C (2002). Development and characterisation of 140 new microsatellites in apple (Malus $x$ domestica Borkh.). Molecular Breeding 10: 217-241. - doi: 10.1023/A:1020525906332

Loiselle BA, Sork VL, Nason J, Graham C (1995). Spatial genetic structure of a tropical understory shrub, Psychotria officinalis (Rubiaceae). American Journal of Botany 82: 1420. - doi: $10.2307 / 2445869$

Ludwig S, Robertson A, Rich TC, Djordjevic M, Cerovic R, Houston L, Harris SA, Hiscock SJ (2013). Breeding systems, hybridization and continuing evolution in Avon Gorge Sorbus. Annals of Botany 111 (4): 563-575. - doi: 10.1093/ aob/mct013

Mock KE, Rowe CA, Hooten MB, Dewoody J, Hipkins VD (2008). Clonal dynamics in western North American aspen (Populus tremuloides). Molecular Ecology 17: 4827-4844. - doi: 10.1111/ j.1365-294X.2008.03963.x

Nagamitsu T, Ogawa M, Ishida K, Tanouchi H (2004). Clonal diversity, genetic structure, and mode of recruitment in a Prunus ssiori population established after volcanic eruptions. Plant Ecology 174: 1-10. - doi: 10.1023/B:VEGE.0000046 $054.87587 .8 \mathrm{~b}$

Oddou-Muratorio S, Guesnet D, Ozdemir E, Petit RJ, Demesure B (2001a). Patterns of seed dispersal in a scattered forest tree species (Sorbus torminalis) based on multi-scale investigation of population genetic structure for chloroplast DNA. In: "Genetic Response of Forest Systems to Changing Environmental Conditions" (Müller-Starck $G$, Schubert R eds). Forestry Sciences vol. 70, Springer, Netherlands, pp. 271-280. doi: 10.1007/978-94-015-9839-2_22

Oddou-Muratorio S, Aligon C, Decroocq S, Plomion C, Lamant T, Mush-Demesure B (2001b). Microsatellite primers for Sorbus torminalis and related species. Molecular Ecology Notes 1 (4): 297-299. - doi: 10.1046/j.1471-8278.2001.00116.x Oddou-Muratorio S, Houot ML, DemesureMusch B, Austerlitz F (2003). Pollen flow in the wild service tree, Sorbus torminalis (L.) Crantz. I. Evaluating the paternity analysis procedure in continuous populations. Molecular Ecology 12: 3427-3439. - doi: 10.1046/j.1365-294X.2003.019 89. $x$

Oddou-Muratorio S, Demesure-Musch B, Pelis- sier R, Gouyon PH (2004). Impacts of gene flow and logging history on the local genetic structure of a scattered tree species, Sorbus torminalis L. Crantz. Molecular Ecology 13: 36893702. - doi: 10.1111/j.1365-294X.2004.02373.x

Oddou-Muratorio S, Klein EK (2008). Comparing direct $v s$. indirect estimates of gene flow within a population of a scattered tree species. Molecular Ecology 17: 2743-2754. - doi: 10.1111/j.1365294X.2008.03783.X

Ortego J, Bonal R, Munoz A (2010). Genetic consequences of habitat fragmentation in longlived tree species: the case of the mediterranean Holm Oak (Quercus ilex L.). Journal of Heredity 101: 717-726. - doi: 10.1093/jhered/esq 081

Ozolinčius R, Lekevičius E, Stakenas V, Galvonaite A, Samas A, Valiukas D (2013). Lithuanian forests and climate change: possible effects on tree species composition. European Journal of Forest Research 133 (1): 51-60. - doi: 10.1007/ S10342-013-0735-9

O'Connell L, Ritland K (2004). Somatic mutations at microsatellite loci in western redcedar (Thuja plicata: Cupressaceae). Journal of Heredity 95: 172-176. - doi: 10.1093/jhered/esho24

Pritchard JK, Stephens M, Donnelly P (2000). Inference of population structure using multilocus genotype data. Genetics 155: 945-959. [online] URL: http://www.genetics.org/content/155 /2/945.short

Pyttel P, Kunz J, Bauhus J (2013). Growth, regeneration and shade tolerance of the Wild Service Tree (Sorbus torminalis (L.) Crantz) in aged oak coppice forests. Trees 27: 1609-1619. - doi: 10.1007/s00468-013-0908-7

Rasmussen KK, Kollmann J (2004). Poor sexual reproduction on the distribution limit of the rare tree Sorbus torminalis. Acta Oecologica 25: 211-218. - doi: 10.1016/j.actao.2004.02.001

Rasmussen KK, Kollmann J (2007a). Genetic diversity, spatial patterns, and growth of root sprouts in a temperate tree at the northern distribution limit. Ecoscience 14: 250-258. - doi: 10.2980/1195-6860(2007)14[250:Gdspag]2.o.Co; 2

Rasmussen KK, Kollmann J (2007b). Low genetic diversity in small peripheral populations of a rare European tree (Sorbus torminalis) dominated by clonal reproduction. Conservation Genetics 9: 1533-1539. - doi: 10.1007/s10592-007-94 92-y

Rich T, Houston L, Robertson A, Proctor M (2010). Whitebeams, rowans and service trees of Britain and Ireland. A monograph of British and Irish Sorbus L. BSBI Handbook no. 14, Botanical Society of the British Isles, London, UK, pp. 229.

Schnittler M, Eusemann P (2010). Consequences of genotyping errors for estimation of clonality: a case study on Populus euphratica Oliv. (Salicaceae). Evolutionary Ecology 24: 1417-1432. doi: 10.1007/s10682-010-9389-y

Stoeckel S, Masson JP (2014). The exact distributions of $F(I S)$ under partial asexuality in small finite populations with mutation. PloS ONE 9: e85228. - doi: 10.1371/journal.pone.0085228

Stoeckel S, Grange J, Fernandez-Manjarres JF, Bilger I, Frascaria-Lacoste N, Mariette S (2006). Heterozygote excess in a self-incompatible and partially clonal forest tree species - Prunus avium L. Molecular Ecology 15: 2109-2118. - doi: 10.1111/j.1365-294X.2006.02926.x

Tarnawski A (2001). Jarzab brekinia w regionie grudziadzkim [Wild service tree in the region Grudziadz]. SAR POMORZE - Bydgoszcz, Grudziadz, Poland, pp. 48.

Tuskan GA, Difazio S, Jansson S, Bohlmann J, Grigoriev I, Hellsten U, Putnam N, Ralph S, Rombauts S, Salamov A, Schein J, Sterck L, Aerts A, Bhalerao RR, Bhalerao RP, Blaudez D, Boerjan W, Brun A, Brunner A, Busov V, Campbell $M$, Carlson J, Chalot M, Chapman J, Chen GL, Cooper D, Coutinho PM, Couturier J, Covert S, Cronk Q, Cunningham R, Davis J, Degroeve S, Dejardin A, dePamphilis C, Detter J, Dirks B, Dubchak I, Duplessis S, Ehlting J, Ellis B, Gendler K, Goodstein D, Gribskov M, Grimwood J, Groover A, Gunter L, Hamberger B, Heinze B, Helariutta $Y$, Henrissat B, Holligan D, Holt R, Huang $W$, Islam-Faridi $N$, Jones $S$, JonesRhoades M, Jorgensen R, Joshi C, Kangasjarvi J, Karlsson J, Kelleher C, Kirkpatrick R, Kirst M, Kohler A, Kalluri U, Larimer F, Leebens-Mack J, Leple JC, Locascio P, Lou Y, Lucas S, Martin F, Montanini B, Napoli C, Nelson DR, Nelson C, Nieminen K, Nilsson $O$, Pereda $V$, Peter $G$, Philippe R, Pilate G, Poliakov A, Razumovskaya J, Richardson P, Rinaldi C, Ritland K, Rouze P, Ryaboy D, Schmutz J, Schrader J, Segerman B, Shin H, Siddiqui A, Sterky F, Terry A, Tsai CJ, Uberbacher E, Unneberg P, Vahala J, Wall K, Wessler S, Yang G, Yin T, Douglas C, Marra M, Sandberg G, Van de Peer Y, Rokhsar D (2006). The genome of black cottonwood, Populus trichocarpa (Torr. \& Gray). Science 313 (5793): 1596-1604. - doi: 10.1126/science.1128691

Vallejo-Marín M, Dorken ME, Barrett SCH (2010). The ecological and evolutionary consequences of clonality for plant mating. Annual Review of Ecology, Evolution, and Systematics 41: 193-213. - doi: 10.1146/annurev.ecolsys.110308.120258

Vaughan SP, Cottrell JE, Moodley DJ, Connolly T, Russell K (2007). Clonal structure and recruitment in British wild cherry (Prunus avium L.). Forest Ecology and Management 242: 419-430. doi: 10.1016/j.foreco.2007.01.059

Vekemans X, Hardy OJ (2004). New insights from fine-scale spatial genetic structure analyses in plant populations. Molecular Ecology 13: 921-935. - doi: 10.1046/j.1365-294X.2004.02076.x Wagner V, Durka W, Hensen I (2011). Increased genetic differentiation but no reduced genetic diversity in peripheral vs. central populations of a steppe grass. American Journal of Botany 98: 1173-1179. - doi: 10.3732/ajb.1000385

Wang $J$ (2011). Unbiased relatedness estimation in structured populations. Genetics 187: 887901. - doi: 10.1534/genetics.110.124438

Wilk JA, Kramer AT, Ashley MV (2009). High variation in clonal vs. sexual reproduction in populations of the wild strawberry, Fragaria virginiana (Rosaceae). Annals of Botany 104: 1413-1419. - doi: 10.1093/aob/mcp239

Wyman J, Bruneau A, Tremblay M-F (2003). Microsatellite analysis of genetic diversity in four populations of Populus tremuloides in Quebec. Canadian Journal of Botany 81: 360-367. - doi: 10.1139/cjfr-2014-0566

Yakimowski SB, Eckert CG (2008). Populations do not become less genetically diverse or more differentiated towards the northern limit of the 
geographical range in clonal Vaccinium stamineum (Ericaceae). New Phytologist 180: 534544. - doi: 10.1111/j.1469-8137.2008.02582.x Young A, Boyle T, Brown T (1996). The population genetic consequences of habitat fragmentation for plants. Trends in Ecology and Evolution 11: 413-418. - doi: 10.1016/0169-5347(96)100 $45-8$

\section{Supplementary Material}

Tab. S1 - Characteristics of 13 nuclear microsatellite loci studied in 172 individuals of Sorbus torminalis (L.) Crantz.

Tab. S2 - Details about the optimized multiplex-PCR reaction mixture.

Tab. S3 - Details about the clonal structure of 172 ramets assigned to 100 genets (geographic coordinates are given in the ETRS89/Poland CS92 coordinate system).
Fig. S1 - Spatial distribution of clonal groups in the fragment of population Rogozno. Different colors indicate ramets of the same clone.

Fig. S2 - Results of clustering of individuals of five populations into three clusters based on STRUCTURE and BAPS software.

Link: Jankowska-Wroblewska_1885@suppl 001.pdf 